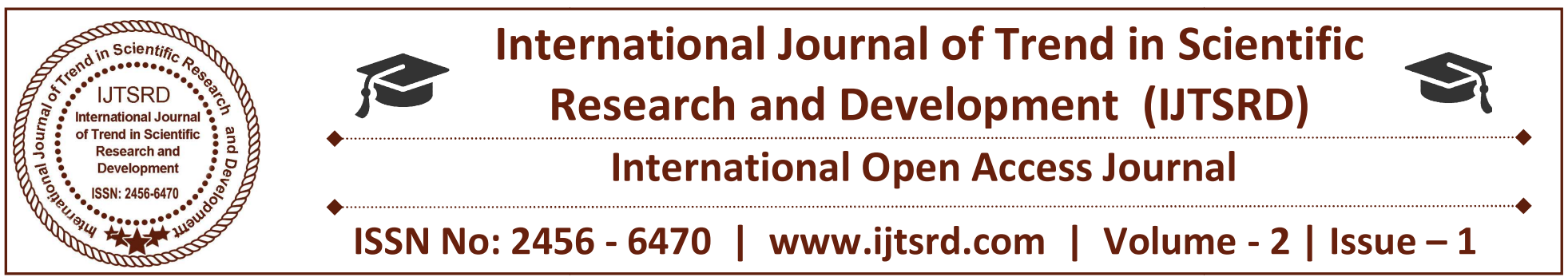

\title{
A Study on Antioxidants (Vitamin c \& e) in Cannabis User in Diabetic and Non-diabetic Subjects
}

\author{
Dr. Ghanshyam Gahlot \\ Biochemist, Sardar Patel Medical College, \\ Bikaner, Rajasthan, India
}

\author{
Dr. Yogita Soni \\ Sardar Patel Medical College, \\ Rajasthan, Bikaner, India
}

\section{ABSTRACT}

Aim \& Objectives: The correlation of Cannabis user groups with duration of one-month, one-year and five year (Both diabetic and non-diabetic groups) with serum Vitamin $\mathrm{C}$ level and serum vitamin E level.

Research Design and Methods: In a cross-sectional, case-control study, we studied cannabis user 55 and 50 cannabis non-user, male-subjects aged between 25 and 65 years. Fasting blood samples were obtained from 55 diabetic male subjects and 50 healthy control subjects. Blood samples were withdrawn who were taking 5 to $10 \mathrm{gm}$ of cannabis per day and analyzed for Antioxidant serum Vitamin $\mathrm{C}$ and serum vitamin $\mathrm{E}$ by standard technique using UVSpectrophotometer.

Results: serum Vitamin $\mathrm{C}$ and serum vitamin $\mathrm{E}$ were measured and the results were compared with those of controls. Antioxidants levels were found to be significantly higher in diabetic and non-diabetic subjects using cannabis 5 to 10 gm per day for the last one month, one year and five years when compare with normal control and diabetic control subjects $(\mathrm{p}<0.01)$.

Conclusion: Study shows a significant increased in Vitamin $\mathrm{C}$ and serum vitamin $\mathrm{E}$ level recorded diabetic patients and non diabetic groups using cannabis for the last one year and five year as well as in the whole group as compared to that of normal control. It might be possible that either cannabis may enhanced the insulin release or increase the penetration of sugar into the cells and might be due to antioxidant activity of cannabis.
Keywords: Diabetes Mellitus, Cannabis sativa, Antioxidants (Vitamin $C \& E$ ).

\section{INTRODUCTION}

Diabetes mellitus (DM) is not a single disease entity but rather a multi systemic metabolic disorder showing the common underlying feature of hyperglycemia. ${ }^{1}$ Oxidative stress thought to be increased in a system where the rate of free radical production is increased and/or the antioxidant mechanisms are impaired. ${ }^{2}$ Increased oxidative stress is a widely accepted participant in the development and progression of diabetes and its complications. ${ }^{3} \mathrm{~A}$ well established correlation exists between development of macro and micro vascular disease in diabetes mellitus. ${ }^{4}$ Vascular endothelial cells are an important target of hyperglycemic damage, but the mechanisms underlying this damage are not fully understood. Early marker of such damage is the development of an endothelial dysfunction. ${ }^{5}$ The chronic complications of DM affect many organ systems and are responsible for the majority of morbidity and mortality associated with the disease. ${ }^{6}$ Hence the aim of the present was to evaluate the oxidative stress in type $2 \mathrm{DM}$ and follow-up along with vitamin E supplementation.

The prevalence of type 2 diabetes mellitus (DM) is increasing, and it is projected that in the USA alone, type $2 \mathrm{DM}$ will increase to 48.3 million by $2050 .{ }^{7}$ In addition to defects in pancreatic b-cell function and insulin sensitivity, systemic inflammation is thought to be involved in its pathogenesis. ${ }^{7,8}$ Marijuana is the most commonly used illicit drug in the USA and is currently used by 14.4 million Americans. ${ }^{9}$ The Cannabis sativa (marijuana) plant contains bioactive 
components termed cannabinoids (CB). The major psychoactive $\mathrm{CB}$ is delta 9-tetrahydrocannabinol (THC) whose effect is mediated through the CB1 and the $\mathrm{CB} 2$ subtypes of $\mathrm{CB}$ receptors found in the brain and lymphoid tissues. ${ }^{10}$ The endo-cannabinoids, a group of neuromodulatory lipids also bind to these receptors. ${ }^{11}$ Cannabis, THC and other CBs have been shown to have both beneficial ${ }^{12}$ and detrimental effects. ${ }^{13}$ Marijuana users have higher caloric intake while eating less nutrient-rich foods, ${ }^{14}$ yet have similar ${ }^{14}$ or slightly lower ${ }^{15}$ body mass index (BMI) than non users. We hypothesised that the prevalence of DM would be reduced in marijuana users due to the presence of one or more CBs because of their immunomodulatory and anti-inflammatory properties. $^{10}$ we assessed the association between DM with antioxidants level and marijuana use among adults aged 25 to 65 years in a Bikaner zone sample of the general population. ${ }^{15}$

Antioxidants such as $\alpha$-tocopherol and Ascorbic acid 16,17 are effective neuroprotectans because of their ability to reduce the toxic reactive oxygen species (ROS) formed during is chemical metabolism.

Cannabinoids like (-) $\Delta^{\mathbf{9}}$ - tetrahydrocannabinol (THC) and its psychoactive analogues also have been reported to be neuroprotective against glutamate toxicity in vitro. ${ }^{17}$ Cannabinoids have been suggested to prevent glutamate neurotoxicity by activating Cannabinoid receptors, which can reduce calcium influx through voltage sensitive calcium channels. ${ }^{18}$

\section{MATERIALS AND METHODS}

The present study was conducted on 105 malesubjects aged between 25 and 65 years during the period of August 2011 to October 2013.They were randomly selected irrespective their caste and creed. Those individuals who were suffering from other inflammatory conditions like tuberculosis, leprosy, pregnancy, cancer, skin diseases, gout, liver and kidney diseases were excluded to rule out any increase in inflammatory markers due to causes other than DM. They were divided into the following groups (Table 1).

Only those subjects included in the present study, who were taking 5 to $10 \mathrm{gm}$ of cannabis per day. Majority of these subjects were Brahmin by caste, belonging to lower middle class. After their small earning, they spent their rest of time in worshiping lard Shiva and residing in temple area called "Bagechi". There they used to take cannabis "bhang" routinely in-group of 58 persons in the form of semi solid mass or in solution form.

They presented themselves voluntarily for the present study on the basis of personal request, relationship and their eternal eagerness to know about the effect of "Bhang" $5 \mathrm{ml}$ of venous blood samples collected at the time of presentation of patients OPD in EDTA bottles and samples were centrifuged at $3000 \mathrm{rpm}$ for 10 minutes. Plasma was collected taking care to avoid hemolysis. (Table I).

The samples were analyzed for the following parameters by UV-Spectrophotometer using standardized Dipyridyl method are serum vitamin E by Barker and Frank (Varley, 1976) ${ }^{20}$ and Serum ascorbic acid was estimated by Roe and Kuethe (1943) using 2,4-dinitrophenylhydrazine. ${ }^{19}$ Estimation of vitamin $\mathrm{E}$ was done by colorimetric method as described by Barker and Frank (Varley, 1976) using reagent. ${ }^{20}$

\section{RESULTS}

The present study was conducted on 105 male subjects aged between 25 and 65 years, comparising of 85 volunteers acted as study group and 20 normal healthy subjects acted as control. The study group was further divided into three groups' viz. diabetic subjects and cannabis user normal as well as cannabis user diabetic subjects. The cannabis user subjects (Both diabetic and non- diabetic) were further subdivided into their sub-groups viz. Chronic, Subchronic and Acute groups (Table-I) depends upon the duration for which they were using cannabis.

The blood samples as control as well as study groups were withdrawn and analyzed for $\alpha$-tocopherol and Ascorbic acid concentration. In this study, table IV,V show that the increase in blood parameters for normal healthy subjects that is normal control group and Diabetic control subjects and parameters represent Mean and SD along with $\mathrm{p}$ value which show highly significant $(\mathrm{p}<.001)$ when compared to Diabetic control subjects as well as Increased level in serum vitamin $\mathrm{E} \& \mathrm{C}$ level in normal control cannabis user (Diabetic and Non-Diabetic) subjects was statistically significant as compared to that of normal control as evident by $\mathrm{P}$-value $(\mathrm{P}<0.001)$. This indicates that lipid peroxidation is significantly increased and antioxidants (Vitamin-C \& E) level significantly decreased in diabetes but cannabis user has 
significantly increased in antioxidants (Vitamin-C \& E) level.

\section{DISCUSSION}

It is revealed that the mean serum vitamin $E$ level was found to be raised to $1.75 \pm 0.24$ with a ranged of 1.42 to $2.06 \mathrm{mg}$ percent in normal control subjects using 5 to $10 \mathrm{gm}$ cannabis per day for the last one month (Table IV). Increase in serum vitamin $\mathrm{E}$ level in normal control cannabis user subjects was statistically significant as compared to that of normal control as evident by $\mathrm{P}$-value $(\mathrm{P}<0.001$; Table IV). The values of vitamin $\mathrm{E}$ level in normal control subject were in close agreement with the finding of Bellizzi et al (1997). ${ }^{21}$ The vitamin $\mathrm{E}$ level in normal control subjects using cannabis for the last one year ranged from 1.88 to 2.61 with an average of $2.11 \pm 0.30 \mathrm{mg}$ percent (Table IV). Where, it ranged from 2.01 to 3.51 with a mean of $2.81 \pm 0.56 \mathrm{mg}$ percent in those normal subjects using cannabis 5 to 10 gm per day for the last five year (Table IV).

The serum vitamin E level was increased significantly in all the groups taking cannabis for the various duration of intake as shown by $\mathrm{P}$ value which is less than 0.001 in all the groups (Table IV). The increase in vitamin $\mathrm{E}$ concentration in cannabis users might be due to the antioxidant activity of cannabis, which spared the vitamin $\mathrm{E}$ to be utilized for free radical scavenger antioxidant activity. ${ }^{22}$

Oxidative stress has been produced by diabetes mellitus which in turn increased the production of free radical species and $\alpha$-tocopherol acted as free radical scavengers and acted as antioxidant and get itself oxidized to quinine form as reported by Machin \& Lawrense $(1991)^{22}$. This may lead to decreased the vitamin $\mathrm{E}$ concentration in diabetic subjects as compared to that of control.

The serum vitamin E concentration was found to be $0.33 \pm 0.15$ with a range of 0.15 to $0.67 \mathrm{mg}$ percent in diabetic subjects using 5 to 10 gm cannabis per day for the last one month (Table V). The increase in vitamin $\mathrm{E}$ level in diabetic subjects using cannabis was not significant as revealed by $\mathrm{P}$-value $(\mathrm{P}<0.2$; Table V) as compared to that of diabetic controls.

The vitamin $\mathrm{E}$ level was ranged from 0.82 to 3.15 with an average of $1.88 \pm 0.84 \mathrm{mg}$ percent in diabetic subjects using cannabis for the last one year; while it was $2.38 \pm 0.53$ with a range of 1.36 to $3.18 \mathrm{mg}$ percent in those diabetic subjects using 5 to $10 \mathrm{gm}$ cannabis per day for the last five years.

Further, it is observed from table II that vitamin E concentration was found to be $1.87 \pm 0.97$ with a range of 0.15 to $3.21 \mathrm{mg}$ percent in cannabis user diabetic subjects as a whole group (Table II).

It is observed from these data that vitamin E concentration was found to be increased significantly in both the cannabis user groups who used to take cannabis for the last one year and five years as well as cannabis user group as a whole as evident by P-value which is less than 0.001 in all the groups (Table II and $\mathrm{V})$. The increase in vitamin $\mathrm{E}$ concentration in cannabis user groups might be due to antioxidant activity of cannabis, which spares the vitamin $E$ to be utilized for free radical scavengers.

It is observed from Table III that the vitamin E level in normal cannabis users was found to be $2.37 \pm 0.63$ and $1.87 \pm 0.97 \mathrm{mg}$ percent respectively. The decreased in vitamin $\mathrm{E}$ concentration in diabetic cannabis users was not highly significant as compared to non-diabetic cannabis users as evident by $\mathrm{P}$-value $(\mathrm{P}<0.05$;table III). However, slight decreased in diabetic cannabis users might be due to stress produced by diabetes mellitus may over product the free radical species and vitamin $\mathrm{E}$ acted as scavenger to excess of free radicals resulted decreased to level. Although cannabis might has similar effect in both the groups of normal \& diabetic.

The mean vitamin $\mathrm{C}$ level was found to be $1.99 \pm 0.24$ with a range of 1.63 to $2.31 \mathrm{mg}$ percent in normal control subjects using 5 to 10 gm cannabis per day for last one month (Table IV) increase in serum vitamin $\mathrm{C}$ level in normal control cannabis user group was statistically significant as compared to that of normal control as evident by $\mathrm{P}$-value $(\mathrm{P}<0.001$; Table IV). The values of ascorbic acid in normal control were resembled with finding Groff et al (1995) ${ }^{23}$.

The serum vitamin $\mathrm{C}$ level ranged from 1.95 to 3.07 with an average of $2.32 \pm 0.45 \mathrm{mg}$ percent in control subjects using cannabis for the last one year while it ranged from 2.35 to 3.51 with an average of $2.91 \pm$ $0.40 \mathrm{mg}$ percent in those control subjects using 5 to $10 \mathrm{gm}$ cannabis per day for last five years (Table IV).

The serum vitamin $\mathrm{C}$ level was increased significantly in all the groups taking cannabis for different period of intake under study as shown by P-value which is less than 0.001 in all the groups (Table IV). The 
increase in vitamin $\mathrm{C}$ might be due to the fact that it acts as antioxidant to protect cellular component from free radical damage and also it reduces the toxic reactive oxygen species (ROS) as reported by Macgregor et al (1996) ${ }^{24}$. However, cannabis might have acted as antioxidant \& performed similar function in cannabis user \& spared the vitamin $\mathrm{C}$ resulting increased its level.

The serum ascorbic acid level was found to be $0.34 \pm$ 0.17 with a range of 0.13 to $0.59 \mathrm{mg}$ percent in diabetic subjects using 5 to $10 \mathrm{gm}$ cannabis per day for last one month (Table V). The increase in vitamin $\mathrm{C}$ level in cannabis user diabetic subjects was not significant as compared to diabetic control as evident by $\mathrm{P}$-value $(\mathrm{P}<0.4$; table $\mathrm{V})$.

Further, it is observed from table $\mathrm{XV}$ that vitamin $\mathrm{C}$ concentration varied from 0.13 to 3.35 with an average of $1.91 \pm 0.98 \mathrm{mg}$ percent in cannabis user diabetic subjects as a whole group (Table II). The increase was statistically significant as compared to diabetic control group $(0.26 \pm 0.09)$ as evident by $\mathrm{P}$ value $(\mathrm{P}<0.001$; table II $)$.

Thus, it is observed that ascorbic acid level was found to be increased significantly in both the cannabis user groups who used to take cannabis for the last one year and five year as well as cannabis user group as a whole as evident by $\mathrm{P}$-value which is less than 0.001 in all the groups (Table V). The increase in vitamin $\mathrm{C}$ level might be due to compensatory mechanism of cannabis as antioxidant activity, which spared vitamin $\mathrm{C}$ leading to increase its level in cannabis user group.

It is observed from Table III that the vitamin C level in normal cannabis users and diabetic cannabis users were found to be $2.53 \pm 0.54$ and $1.91 \pm 0.98 \mathrm{mg}$ percent respectively. The decrease in vitamin C concentration in diabetic cannabis users was not highly significant as compared to that of non-diabetic cannabis users as evident by $\mathrm{P}$-value $(\mathrm{P}<0.05$; table III). However, slight decrease in diabetic cannabis users might due to diabetic stress which may caused over production of reactive oxygen species (ROS) and vitamin $\mathrm{C}$ acted as antioxidant to nullify the adverse effect of ROS resulting decreased its own concentration in cannabis diabetic subjects. Although cannabis might has similar effect in both normal and diabetic groups.

\section{CONCLUSION}

A significant increase in vitamin $\mathrm{E} \& \mathrm{C}$ level were recorded in normal subjects using cannabis 5 to $10 \mathrm{gm}$ per day for the last one month as compared to that of normal control, both Serum vitamin E,C level were found to be increased significantly in normal cannabis user group as a whole as well as those normal subjects using cannabis for the last one-year and five year as compared to normal control group; it might be sparing action of cannabis for the vitamin E,C.

A decreased concentration of vitamin $\mathrm{E} \& \mathrm{C}$ were recorded in diabetic subjects as compared to that of control group oxidative stress of diabetes caused increased production of reactive oxygen species (ROS), which in turn decreased vitamin $\mathrm{E}, \mathrm{C}$ levels in diabetes.

A slight increased in vitamin $\mathrm{E}, \mathrm{C}$ concentration in diabetic subject using 5 to 10 gm cannabis per day for the last one month as compared to that of diabetic control.

A significant increase in vitamin $\mathrm{E} \& \mathrm{C}$ concentration were recorded in diabetic cannabis user group as a whole and also in those diabetic subject using cannabis 5 to $10 \mathrm{gm}$ per day for the last one year as well as for 5 year as compared to that of diabetic control due to sparing action of cannabis for the vitamin $\mathrm{E}, \mathrm{C}$.

A decreased level of vitamin C \& E were recorded in diabetic subjects as compared to that non-diabetic control group. It might be oxidative stress of diabetes, which result increased production of reactive oxygen species (ROS), which in turn decreased vitamin C level in diabetes subjects.

A significant increase in vitamin E, C level was recorded in diabetic cannabis user group as a whole and also in that diabetic subject using 5 to $10 \mathrm{gm}$ cannabis per day for the last one year as well as for 5 year as compared to that of diabetic control. It might be due to compensatory action of cannabis for the vitamin $\mathrm{C}$.

\section{STATISTICAL ANALYSIS:}

Frequencies, proportions, means, and SDs were used to describe the overall sample, and the marijuana users and non-users. Student's t-test and chi-square tests were used to compare the descriptive statistics 
depending on data type. Data was analyzed using SPSS statistical package version 21 (SPSS, Inc, Chicago, IL).

ACKNOWLEDGEMENTS: We are grateful the Principal, H.O.D., Teaching, Non-teaching staff, PG students and technical staff in the Biochemistry Department, S. P. Medical College, Bikaner, Rajasthan for their co-operation during complete research.

\section{REFERENCES}

1) Maitra A, Abbas R. and Cotran. Pathologic basis of disease, 7th ed. 2004. p. 1191-2.

2) Irshad M, Chaudhari P.S. Oxidant and antioxidant system: role and significance in human body. Indian J Exp Biol. 2002; 40:1:1233-9.

3) Ramakrishna V, Jailkhani R. Evaluation of oxidative stress in Insulin Dependent Diabetes Mellitus (IDDM) patients. Diagnos. Pathology. 2007; 1746-1596-2-22.

4) Heistad and Donald D. Oxidative stress and vascular disease. Arterioscleroses Thromb. Vasc Biol. 2005; 26:689-95.

5) Coesention F, Luscher TF. Endothelial dysfunction in diabetes mellitus. J. Cardiovasc Pharmacol. 1998; 32(Suppl 13):554-61.

6) Powers AC. In: Kasper D, Braunwald E, et al., editors. Diabetes mellitus in Harrison's principles of internal medicine, 16th ed. McGraw-Hill Companies; 2008. p. 2161-2.

7) Narayan KM, Boyle JP, Geiss LS, et al. Impact of recent increase in incidence on future diabetes burden: U.S., 2005-2050. Diabetes Care 2006; 29:2114e16.

8) $\mathrm{Hu} \mathrm{FB}$, Meigs JB, Li TY, et al. Inflammatory markers and risk of developing type 2 diabetes in women. Diabetes 2004; 53: 693e700.

9) Substance Abuse and Mental Health Services Administration. Results from the 2006 National Survey On Drug Use and Health: National Findings, NSDUH Series H-32 (DHHS Publication No. SMA 07e4293). Rockville, MD: Substance Abuse and Mental Health Services Administration, 2007. http://www.oas.samhsa.gov/nsduh/ 2k7nsduh/2k7Results.pdf (accessed 18 Aug 2009).

10) Carrier EJ, Patel S, Hillard CJ. Endocannabinoids in neuroimmunology and stress. Curr Drug Targets CNS Neurol Disord 2005; 4:657e65.

11) Devane WA, Hanus L, Breuer A, et al. Isolation and structure of a brain constituent that binds to the cannabinoid receptor. Science 1992;258:1946e9

12) Robson $P$. Therapeutic aspects of cannabis and cannabinoids. Br J Psychiatry 2001; 178:107e15.

13) Polen MR, Sidney S, Tekawa IS, et al. Health care use by frequent marijuana smokers who do not smoke tobacco. West J Med 1993; 158:596e601.

14) Rodondi N, Pletcher MJ, Liu K, et al; Coronary Artery Risk Development in Young Adults (CARDIA) Study. Marijuana use, diet, body mass index, and cardiovascular risk factors (from the CARDIA study). Am J Cardiol 2006; 98:478e84.

15) Smit E, Crespo CJ. Dietary intake and nutritional status of US adult marijuana users: results from the Third National Health and Nutrition Examination Survey. Public Health Nutr 2001; 4:781

16) Macgregor D.G., Higgings M.J., Jones.P.A., Maxwell W.L., Watson M.W., Graham D.I. \& Stone T.W. Brain Res. 1996; 727: 133.

17) Skaper S.D., Buriani A., Dal Toso R., Petrell I.L., Romanello L., Facci L. and. Leon A. Cannabidiol and delta-0-tetrahydrocannabinol are neuroprotective antioxidants" Proc. Natl. Acad. Sci. USA.1996; $93: 3984$.

18) Twithchell W., Brown S. \& Mackie K. Cannabinoids Inhibit N- and P/Q-Type Calcium channels in Rat Hippocampal. J. Neurochem.1997; $78,43$.

19) Roe J.H. and Kuether C.A. Determination of ascorbic acid in whole blood and urine through the 2,4-Dinitrophenyl hydrazine derivative of dehydroascorbic acid. J. Bio. Chem. 1943; 147:399.

20) Varley H., Gowenlock A.H. and Bell M. Practical clinical Biochemistry". Heinemann Medical Books. London.1976; vol.2:222.

21) Bellizzi M.C., Dutta Roy A.K. and Jame W.P.T. High-D-Glucose dose not effect binding of $\alpha$ tocopherol to human erythrocytes. Mol. Cell Biochem.1997; 170:180.

22) Machlin,J. and Lawrense. Vitamin-E. Hand Book of Vitamins, $2^{\text {nd }}$ Marcel Dekker. Madison Avenue, New York. 1991; pp. 114.

23) Groff J.L., Gropper S.S. and Hunt S.M. The water-soluble vitamins. In; Advanced Nutrition and Human Metabolism: Minneapolis.West Publishing Company. 1995; PP 222.

24) Macgregor D.G., Higgings M.J. Jones P.A., Maxwell W.L., Watson M.W., Graham D.I. \& Stone T.W. Brain Res. 1996;.727 : 133. 


\section{OBSERVATION}

\section{Table-I}

\begin{tabular}{|l|l|c|}
\hline S.No. & GROUP & NUMBER OF SUBJECT \\
\hline 1. & I $^{\text {st }}$ normal control & 20 \\
\hline 2. & II $^{\text {ed }}$ Diabetic subjects & 30 \\
\hline 3. & III $^{\text {ed }}$ Normal Subject cannabis user & 30 \\
\hline 4. & IV $^{\text {th }}$ Diabetic subjects cannabis user & 25 \\
\hline
\end{tabular}

\section{TABLE II - MEAN VALUES OF BLOOD PARAMETERS IN DIABETIC CONTROL SUBJECTS USING CANNABIS COMPARE WITH THAT OF DIABBETIC CONTROL}

\begin{tabular}{|c|c|c|c|c|c|c|c|c|}
\hline \multirow[t]{2}{*}{ Blood Parameters } & \multicolumn{3}{|c|}{$\begin{array}{c}\text { Diabetic Control Subjects. } \\
(n=30)\end{array}$} & \multicolumn{3}{|c|}{$\begin{array}{c}\text { Diabetic Subjects using } \\
\text { Cannabis. }(n=25)\end{array}$} & \multicolumn{2}{|c|}{ Significant } \\
\hline & Mean \pm S.D & Range & S.E. & Mean \pm S.D & Range & S.E. & $\mathbf{t}$ & $\mathbf{p}$ \\
\hline $\begin{array}{l}\alpha \text {-Tocopherol } \\
\text { (Vit. E) mg\% }\end{array}$ & $0.26 \pm 0.11$ & $0.09-0.51$ & 0.02 & $1.87 \pm 0.97$ & $0.15-3.21$ & 0.19 & 8.47 & $\begin{array}{l}<0.001 \\
\left(\mathrm{HS}^{* *}\right)\end{array}$ \\
\hline $\begin{array}{l}\text { Ascorbic Acid } \\
\text { (Vit. C) } \mathrm{mg} \%\end{array}$ & $0.26 \pm 0.09$ & $0.14-0.44$ & 0.01 & $1.91 \pm 0.98$ & $0.13-3.35$ & 0.19 & 8.68 & $\begin{array}{l}<0.001 \\
\left(\mathrm{HS}^{* *}\right)\end{array}$ \\
\hline
\end{tabular}

HS** = Highly Significant.

TABLE III- COMPARISON OF MEAN VALUES OF BLOOD PARAMETERS IN CANNABIS USER DIABBETIC AND NON-DIABETIC SUBJECTS

\begin{tabular}{|c|c|c|c|c|c|c|c|c|}
\hline \multirow[t]{2}{*}{ Blood Parameters } & \multicolumn{3}{|c|}{$\begin{array}{c}\text { Normal Subjects using } \\
\text { Cannabis. }(n=30)\end{array}$} & \multicolumn{3}{|c|}{$\begin{array}{c}\text { Diabetic Subjects using } \\
\text { Cannabis. }(n=25)\end{array}$} & \multicolumn{2}{|c|}{ Significant } \\
\hline & $\begin{array}{l}\text { Mean } \pm \\
\text { S.D }\end{array}$ & Range & S.E. & $\underset{\text { S.D }}{\operatorname{Mean} \pm}$ & Range & S.E. & $\mathbf{t}$ & $\mathbf{p}$ \\
\hline $\begin{array}{l}\alpha \text {-Tocopherol } \\
\text { (Vit. E) } \mathrm{mg} \%\end{array}$ & $2.37 \pm 0.63$ & $\begin{array}{l}1.42- \\
3.51 \\
\end{array}$ & 0.14 & $1.87 \pm 0.97$ & $0.15-3.21$ & 0.19 & 2.08 & $\begin{array}{c}<\mathbf{0 . 0 5} \\
\left(\mathrm{S}^{*}\right)\end{array}$ \\
\hline $\begin{array}{l}\text { Ascorbic Acid } \\
\text { (Vit. C) } \mathbf{m g} \%\end{array}$ & $2.53 \pm 0.54$ & $1.60-3.51$ & 0.12 & $1.91 \pm 0.98$ & $0.13-3.35$ & 0.19 & 2.81 & $\begin{array}{c}<0.05 \\
\left(\mathrm{~S}^{*}\right)\end{array}$ \\
\hline
\end{tabular}

HS** = Highly Significant. $\quad$ S* $^{*}$ Significant. 
International Journal of Trend in Scientific Research and Development (IJTSRD) ISSN: 2456-6470

TABLE IV - COMPARISON OF MEAN VALUES OF BLOOD PARAMETERS IN NORMAL CONTROL SUBJECTS WITH NORMAL SUBJECTS USING CANNBIS 5 to $10 \mathrm{gm}$ PER DAY FOR THE LAST ONE MONTH, ONE YEAR AND FIVE YEARS.

\begin{tabular}{|c|c|c|c|c|c|c|c|c|c|c|c|c|c|c|}
\hline \multirow[t]{2}{*}{ Blood Parameters } & \multicolumn{2}{|c|}{$\begin{array}{l}\text { Normal } \\
\text { Control } \\
\text { subjects. } \\
(n=20)\end{array}$} & \multicolumn{2}{|c|}{$\begin{array}{c}\text { Normal } \\
\text { Subjects using } \\
\text { Cannabis (for } \\
\text { the last one } \\
\text { month). } \\
(n=7)\end{array}$} & \multicolumn{2}{|c|}{ Significant } & \multicolumn{2}{|c|}{$\begin{array}{l}\text { Normal Subjects } \\
\text { using Cannabis } \\
\text { (for the last one } \\
\text { year). } \\
(\mathrm{n}=\mathbf{8})\end{array}$} & \multicolumn{2}{|c|}{ Significant } & \multicolumn{2}{|c|}{$\begin{array}{l}\text { Normal Subjects } \\
\text { using Cannabis } \\
\text { (for the last five } \\
\text { years). } \\
(n=15)\end{array}$} & \multicolumn{2}{|c|}{$\begin{array}{c}\text { Significan } \\
t\end{array}$} \\
\hline & $\begin{array}{l}\text { Mean } \pm \\
\text { S.D. }\end{array}$ & $\begin{array}{l}\text { S. } \\
\text { E. }\end{array}$ & $\begin{array}{l}\text { Mean } \pm \\
\text { S.D. }\end{array}$ & $\begin{array}{l}\text { S.E } \\
. \\
\end{array}$ & $\mathbf{t}$ & p & $\begin{array}{l}\text { Mean } \pm \\
\text { S.D }\end{array}$ & $\begin{array}{l}\text { S.E } \\
. \\
\end{array}$ & $\mathbf{t}$ & $\mathbf{p}$ & $\begin{array}{l}\text { Mean } \pm \\
\text { S.D. }\end{array}$ & $\begin{array}{l}\text { S.E } \\
.\end{array}$ & $\mathbf{t}$ & $\mathbf{p}$ \\
\hline $\begin{array}{c}\alpha \text {-Tocopherol } \\
\text { (Vit. E) } \\
\text { mg\% }\end{array}$ & $\begin{array}{c}1.02+0.36 \\
(0.30- \\
1.66)\end{array}$ & $\begin{array}{l}0 . \\
08\end{array}$ & $\begin{array}{c}1.75 \pm 0.2 \\
4 \\
(0.42- \\
2.06)\end{array}$ & $\begin{array}{c}0.1 \\
0\end{array}$ & $\begin{array}{c}5.5 \\
4\end{array}$ & $\begin{array}{c}<0.0 \\
01 \\
\text { HS** }\end{array}$ & $\begin{array}{c}2.11 \pm 0.30 \\
(1.88- \\
2.61)\end{array}$ & $\begin{array}{c}0.1 \\
3\end{array}$ & 7.2 & $\begin{array}{c}<0.00 \\
1 \\
\mathrm{HS}^{* *}\end{array}$ & $\begin{array}{c}2.81 \pm 0.56 \\
(2.01- \\
3.51)\end{array}$ & $\begin{array}{c}0.1 \\
7\end{array}$ & $\begin{array}{l}9 . \\
36\end{array}$ & $\begin{array}{c}<0.00 \\
1 \\
\mathrm{HS} * *\end{array}$ \\
\hline $\begin{array}{c}\text { Ascorbic Acid } \\
\text { (Vit. C) } \\
\text { mg\% }\end{array}$ & $\begin{array}{c}1.08 \pm 0.38 \\
(0.37- \\
1.90)\end{array}$ & $\begin{array}{c}0 . \\
08\end{array}$ & $\begin{array}{c}1.99+0.2 \\
4 \\
(1.63- \\
2.31)\end{array}$ & $\begin{array}{c}0.1 \\
0\end{array}$ & $\begin{array}{c}7.0 \\
0\end{array}$ & $\begin{array}{c}<0.0 \\
01 \\
\text { HS** }\end{array}$ & $\begin{array}{c}2.32+0.45 \\
(1.95- \\
3.07)\end{array}$ & $\begin{array}{c}0.1 \\
9\end{array}$ & 6.2 & $\begin{array}{c}<0.00 \\
1 \\
\text { HS** }\end{array}$ & $\begin{array}{c}2.91+0.40 \\
(2.35- \\
3.51)\end{array}$ & $\begin{array}{c}0.1 \\
2\end{array}$ & $\begin{array}{l}4 . \\
46\end{array}$ & $\begin{array}{c}<0.00 \\
1 \\
\text { HS ** }\end{array}$ \\
\hline
\end{tabular}

Figures in parenthesis indicate the range.

TABLE V- COMPARISON OF MEAN VALUES OF BLOOD PARAMETERS IN DIABETIC CONTROL SUBJECTS WITH DIABETIC SUBJECTS USING CANNBIS 5 to 10 gm PER DAY FOR THE LAST ONE MONTH, ONE YEAR AND FIVE YEARS.

\begin{tabular}{|c|c|c|c|c|c|c|c|c|c|c|c|c|c|c|}
\hline \multirow[t]{2}{*}{$\begin{array}{c}\text { Blood } \\
\text { Parameter } \\
\text { s }\end{array}$} & \multicolumn{2}{|c|}{$\begin{array}{c}\text { Diabetic Control } \\
\text { subjects. } \\
(\mathbf{n}=\mathbf{3 0})\end{array}$} & \multicolumn{2}{|c|}{$\begin{array}{l}\text { Diabetic Subjects } \\
\text { using Cannabis } \\
\text { (for the last one } \\
\text { month). } \\
(n=5)\end{array}$} & \multicolumn{2}{|c|}{$\begin{array}{c}\text { Significan } \\
t\end{array}$} & \multicolumn{2}{|c|}{$\begin{array}{l}\text { Diabetic Subjects } \\
\text { using Cannabis } \\
\text { (for the last one } \\
\text { year). } \\
(\mathrm{n}=\mathbf{5})\end{array}$} & \multicolumn{2}{|c|}{ Significant } & \multicolumn{2}{|c|}{$\begin{array}{l}\text { Diabetic Subjects } \\
\text { using Cannabis } \\
\text { (for the last five } \\
\text { years). } \\
(n=15)\end{array}$} & \multicolumn{2}{|c|}{ Significant } \\
\hline & $\begin{array}{l}\text { Mean } \pm \\
\text { S.D. }\end{array}$ & $\begin{array}{c}\text { S.E } \\
.\end{array}$ & $\begin{array}{l}\text { Mean } \pm \\
\text { S.D. }\end{array}$ & S.E. & $\mathbf{t}$ & $\mathbf{p}$ & $\underset{\text { S.D }}{\operatorname{Mean} \pm}$ & S.E. & $\mathbf{t}$ & $\mathbf{p}$ & $\begin{array}{l}\text { Mean } \pm \\
\text { S.D. }\end{array}$ & S.E. & $\mathbf{t}$ & $\mathbf{P}$ \\
\hline $\begin{array}{c}\alpha \\
\text { Tocopherol } \\
\text { (Vit. E) } \\
\text { mg\% }\end{array}$ & $\begin{array}{l}0.26 \pm 0.11 \\
(0.09-0.51)\end{array}$ & $\begin{array}{c}0.0 \\
2\end{array}$ & $\begin{array}{c}0.33 \pm 0.15 \\
(0.15- \\
0.67)\end{array}$ & 0.09 & $\begin{array}{c}0.8 \\
8\end{array}$ & $\begin{array}{r}<0.2 \\
\text { IS }\end{array}$ & $\begin{array}{l}1.88 \pm 0.84 \\
(0.82-3.15)\end{array}$ & 0.37 & 4.41 & $\begin{array}{c}<0.00 \\
1 \\
\text { HS** }\end{array}$ & $\begin{array}{l}2.38 \pm 0.53 \\
(1.36-3.18)\end{array}$ & 0.14 & $\begin{array}{c}13.1 \\
9\end{array}$ & $\begin{array}{c}<0.0 \\
01 \\
\text { HS* } \\
*\end{array}$ \\
\hline $\begin{array}{l}\text { Ascorbic } \\
\text { Acid } \\
\text { (Vit. C) } \\
\text { mg\% }\end{array}$ & $\begin{array}{l}0.26 \pm 0.09 \\
(0.14-0.43)\end{array}$ & $\begin{array}{c}0.0 \\
1\end{array}$ & $\begin{array}{c}0.34+0.17 \\
(0.13- \\
0.59)\end{array}$ & 0.08 & $\begin{array}{c}1.0 \\
0\end{array}$ & $\begin{array}{c}<0.4 \\
\text { IS }\end{array}$ & $\begin{array}{l}1.91 \pm 0.72 \\
(0.94-2.96)\end{array}$ & 0.32 & 5.00 & $\begin{array}{c}<0.00 \\
1 \\
\text { HS** }\end{array}$ & $\begin{array}{l}2.44+0.55 \\
(1.58-3.55)\end{array}$ & 0.14 & $\begin{array}{c}15.5 \\
4\end{array}$ & $\begin{array}{c}<0.0 \\
01 \\
\text { HS* } \\
*\end{array}$ \\
\hline
\end{tabular}

Figures in parenthesis indicate the range. 